\title{
Morphologic change and morphodynamics at high-energy embayed beaches in Southwestern Portugal
}

Loureiro, C., Ferreira, Ó., \& Cooper, A. (2011). Morphologic change and morphodynamics at high-energy embayed beaches in Southwestern Portugal. In J. D. Rosati, P. Wang, \& T. M. Roberts (Eds.), Unknown Host Publication (Vol. 2, pp. 1375-1389). World Scientific Publishing.

Link to publication record in Ulster University Research Portal

\section{Published in:}

Unknown Host Publication

Publication Status:

Published (in print/issue): 01/01/2011

\section{Document Version}

Publisher's PDF, also known as Version of record

\section{General rights}

Copyright for the publications made accessible via Ulster University's Research Portal is retained by the author(s) and / or other copyright owners and it is a condition of accessing these publications that users recognise and abide by the legal requirements associated with these rights.

\section{Take down policy}

The Research Portal is Ulster University's institutional repository that provides access to Ulster's research outputs. Every effort has been made to ensure that content in the Research Portal does not infringe any person's rights, or applicable UK laws. If you discover content in the Research Portal that you believe breaches copyright or violates any law, please contact pure-support@ulster.ac.uk. 


\title{
MORPHOLOGIC CHANGE AND MORPHODYNAMICS AT HIGH-ENERGY EMBAYED BEACHES IN SOUTHWESTERN PORTUGAL
}

\author{
CARLOS LOUREIRO ${ }^{1}$, ÓSCAR FERREIRA ${ }^{1}$, J. ANDREW G. COOPER ${ }^{2}$
}

1. Centre for Marine and Environmental Research, Universidade do Algarve, Campus de Gambelas, 8005-139 Faro, Portugal.cloureiro@ualg.pt; oferreir@ualg.pt.

2. Centre for Coastal and Marine Research, School of Environmental Sciences, University of Ulster, Cromore Road, Coleraine BT52 1SA, Northern Ireland. jag.cooper@ulster.ac.uk.

\begin{abstract}
Along the southwestern coast of Portugal, a high-energy, swell dominated environment with a markedly seasonal wave climate, morphologic change in three embayed beaches was regularly monitored over a two year period. While a general seasonal pattern was identified, the occurrence of a storm group induced dramatic beach response, producing marked interannual variability. Significant spatial variations in behaviour emerged during the monitoring period, inducing alongshore non-uniform beach change within each embayment. Megarips were the prevailing mechanism responsible for the extreme erosion experienced in all three beaches, and their specific location (controlled by topography) contributes to the variability observed within each beach. Despite severe beach erosion, dunes were unaffected, which suggests long-term stability of these high-energy, dissipative, embayed coastlines.
\end{abstract}

\section{Introduction}

Cycles of erosion and accretion in wave-dominated beaches have been extensively studied and documented around the world's coastlines. Initial models of winter "cut" and summer "fill" were progressively replaced by models of cyclic beach change in response to changing wave conditions (Hayes and Boothroyd, 1969; Nordstrom, 1980), and further extended to fully integrate the three-dimensional behaviour of beaches and surf zones (Wright and Short, 1984). Nevertheless, for coastal environments with a strong seasonal wave climate, as in swell-dominated beaches, morphologic change is commonly reflected in erosion and accretion patterns in phase with the seasons (Quartel et al., 2008). Although periodic storm erosion is not unique to any particular season, there is a general tendency for higher intensity and frequency of storms during the winter season (Hayes and Boothroyd, 1969; Fox and Davis, 1978; Quartel et al., 2008). More frequent storms means a shorter timeframe for the slow pace post-storm recovery to occur, and only partial recovery is accomplished before the following storm occurs, preventing complete recovery 
until the end of the storm season (Fox and Davis, 1978). This pattern of morphological change on swell-dominated beaches creates a seemingly seasonal cycle of beach change, with beach volume variation characterized by a postwinter minimum and reaching a maximum volume at the beginning of the winter, following summer accretion (Quartel et al., 2008).

On high-energy dissipative beaches observations of the seasonal pattern of morphological change increased in recent years, highlighting marked alongshore variations in shoreline change (e.g. Ruggiero et al., 2005; Hansen and Barnard, 2010). Alongshore non-uniform morphological change on high-energy dissipative beaches arises because beach response, especially during storms, does not linearly depend on wave conditions (Russell, 1993), due to reduced contribution of the incident wave frequency band in the beach and inner surf zone (Wright et al., 1982; Russell, 1993). Instead, it depends on a combination of waves and infragravity oscillations, tidal phase and surge level, antecedent morphology and geomorphologic control (Cooper et al., 2004; Ruggiero et al., 2005). For embayed beaches on high-energy coastal environments, conditions for alongshore non-uniform response are even more pronounced, as geomorphologic control in beach morphodynamics is highly significant (Jackson et al., 2005), and sediment movement and hydrodynamics in embayed beaches are heavily impacted by headlands (Short, 1999). Earlier reports of alongshore variation in morphological change of embayed beaches exposed to energetic wave conditions identified complex interactions between large scale embayment circulation, particularly those associated with rip currents developed during storms (Eliot and Clarke, 1982). The beach response associated with such large scale rip currents, later termed megarips by Short (1985), was found to vary alongshore and deviate from the seasonal trend of morphological change (Eliot and Clarke, 1982). Recent work has highlighted megarips as an important mechanism of morphological change on embayed beaches (Short, 2010), but they still remain a little studied coastal process (MacMahan et al., 2005).

The aim of this paper is to investigate the variability of beach change in embayed beaches exposed to high-energy wave conditions. The temporal variation, associated with seasonal and episodic changes, as well as the nonuniform alongshore patterns of beach change are analysed, and the morphodynamic mechanisms that drive the observed behaviour are discussed.

\section{Study area}

The southwestern coast of Portugal, a high-energy swell environment, is a bedrock-framed coastline where beaches occur generally in embayments associated with small streams or in coastal re-entrants within the rocky cliffs. Along this coastline three beaches, Amoreira, Monte Clérigo and Arrifana, were selected as study sites (Figure 1). The first two are directly exposed to the 
dominant north-westerly waves while Arrifana roughly faces west and is partially protected by a prominent northern headland. These three relatively short beaches (between 500 and $750 \mathrm{~m}$ long) are composed of well sorted medium sand and, being exposed to a high-energy wave climate, are modally dissipative or intermediate skewed to dissipative in state. Amoreira embayment contains a bay-barrier estuary, with a small tidal stream meandering along the intertidal zone. The beach is wide and backed by an extensive dune field, presenting a persistent low tide terrace occasionally crossed by the tidal stream, which creates a ridge and runnel-like morphology. Monte Clérigo also presents a wide beach backed by dunes in the south and centre, while the northern sector is narrow and backed by 50-m high cliffs. During most of the year the beach is typified by a gently sloping beach face, extending shoreward to the toe of the cliffs on the northern sector. A similar gentle sloping beach face extending to a gravel deposit at the cliff base characterizes Arrifana, a swash aligned beach enclosed by up to $100 \mathrm{~m}$ high cliffs. The subaerial beach is narrow and rarely contains a well defined berm, while the intertidal beach is wide and planar.

Being exposed to the North Atlantic, the coastline of south-western Portugal experiences energetic conditions throughout the year, although with markedly seasonal variation. Mean monthly offshore significant wave heights $\left(H_{s o}\right)$ between 2 and $2.5 \mathrm{~m}$ occur from November to March, while during the remaining months $H_{s o}$ varies from 1 to $2 \mathrm{~m}$ (Costa and Esteves, in press). Wave period follows a similar variation, with monthly peak periods $\left(T_{p}\right)$ between 12 and $14 \mathrm{~s}$ from November to March and 9 to $12 \mathrm{~s}$ during the rest of the year. Peak wave direction (Dirp) is constant throughout the year from NW-W direction (97.4\% of the records) (Costa et al., 2001; Costa and Esteves, in press). Energetic wave conditions are relatively frequent, with $H_{s o}$ exceeding $3 \mathrm{~m}$ on $10 \%$ of the time. Storms along the western Portuguese coast are normally associated with $H_{s o} \geq 5 \mathrm{~m}$ (Pita and Santos, 1989), and are generally caused by high to mid-latitude depressions crossing the North Atlantic towards Western Europe (Costa et al., 2001). Storm groups occur frequently on the west coast of Portugal, on average once every year for groups of two storms and once every four years for a group of three storms (Ferreira, 2005). Tides along the southwestern Portuguese coast are semidiurnal and mesotidal, with maximum spring tidal range of $3.6 \mathrm{~m}$ and maximum tidal elevation approximately $2 \mathrm{~m}$ above mean sea level (MSL). Barometric pressure effects can increase the water levels by up to an additional $0.5 \mathrm{~m}$ (Gama et al., 1994).

\section{Methods}

Topographic surveys were conducted along cross-shore beach profiles on the three beaches. Surveys were performed regularly every two months between September 2007 and September 2009. Episodic surveys were also undertaken 
after each storm and 15 to 30 days later to monitor beach recovery, as surveystorm timing is decisive to understand the variability in beach changes driven by storm events (Quartel et al., 2008). In total, 20 surveys were completed on each beach over the two year period. Three profiles representative of different beach sectors and with alongshore spacing between 100 and $200 \mathrm{~m}$ (Figure 1), were monitored on each beach using RTK-GPS. Surveys were performed always during low tide, preferentially during spring tides, at least up to the mean low water spring level (MLWS), 1.4 m bellow MSL, or further seaward.

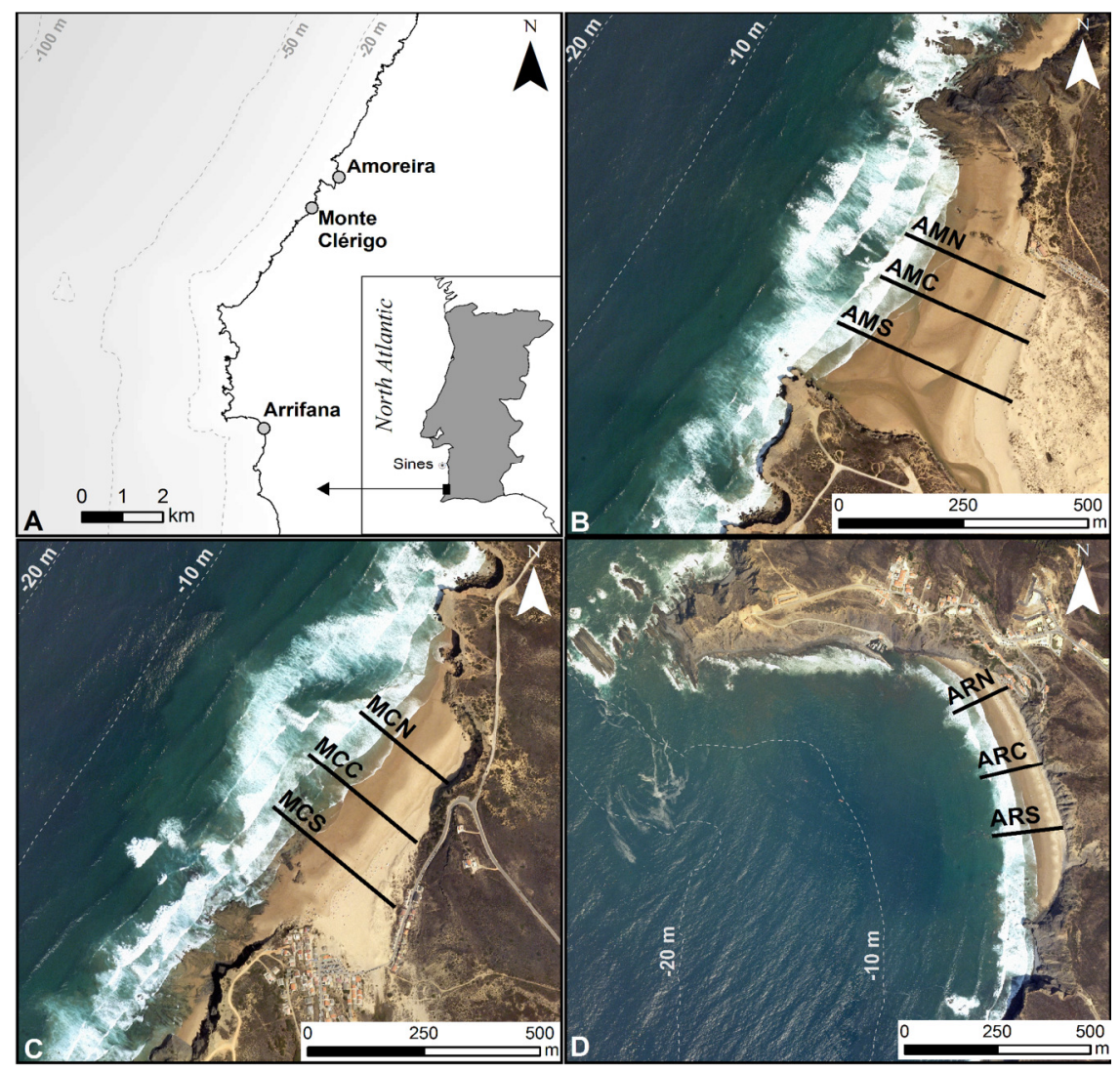

Fig. 1. Location of the study area in the south-western coast of Portugal (A). Amoreira (B), Monte Clérigo (C) and Arrifana embayments with profile identification (black lines).

Wave and tide data were obtained continuously for the entire monitoring period from the Sines deepwater directional wave buoy, located in $97 \mathrm{~m}$ water depth, and from the Port of Sines tide gauge, both approximately $65 \mathrm{~km}$ north of the study area (Figure 1). Gaps in the observed tidal record ( $2 \%$ of the total record) 
where filled using the predicted tide levels, while gaps from the measured wave record ( $20 \%$ of the total record) where filled using modelled data from a close WANA network deepwater grid point (Lahoz and Albiach, 2005), as significant correlation was obtained for $H_{s o}(\rho \leq 0.001, n=6137, R=0.88)$ and $T_{p}(\rho \leq$ 0.001, $n=6137, R=0.61)$. Correlation analysis was also performed between several WANA grid points along the southwest coast of Portugal to determine whether wave conditions close to Sines buoy were representative of the deepwater conditions further south, in locations closer to the study areas. Results indicate a highly significant correlation for both $H_{s o}$ and $T_{p}$ at all points $(\rho \leq$ $0.001, n=8276, R \geq 0.92$ ), suggesting a close similarity of deepwater wave conditions along this stretch of coastline.

Time series of beach width and volume variability were used to quantify beach changes. Beach width was calculated as the horizontal distance from the MSL shoreline position to the cliff base of frontal dune, which has not changed during the monitoring period. MSL was selected for beach width following several works using datum-based shorelines as proxies for beach width change (Farris and List, 2007), particularly using the intersection of the MSL with the foreshore on high-energy environments (e.g. Hansen and Barnard, 2010). Beach profile volume was obtained using trapezoidal integration with the upper limit defined by the profile surface and the MLWS level as lower limit. By taking MLWS level (-1.4 m MSL) as the lower limit for volume calculation it was possible to incorporate the intertidal and subaerial beach change. A similar level, $-1.3 \mathrm{~m}$ MSL, was recently identified for an exposed beach in southern Portugal by Almeida et al. (in press) as a nodal depth separating the cross-shore sectors dominated by berm and subtidal terrace changes, respectively above and below that depth. The existence of a nodal point at a depth close to MLWS level appears to indicate a vertical morphodynamic separation of the profile at this level, rendering it as an appropriate lower level for volume calculation. Net gain or loss of sediment over the MLWS level is then considered an indicator of cross-shore exchange of sediment between (i) the subaerial and intertidal beach and (ii) the subtidal beach. Profile volumetric mobility and envelopes where computed following Dolan et al. (1978). Mobility is defined as standard deviation of the mean profile volume $( \pm \sigma)$, while the envelope corresponds to the maximum and minimum values of the detrended beach volume time series.

\section{Results}

\section{Wave forcing}

Daily averages of offshore wave conditions, (Figure 2) indicate that the largest values typically occur during winter (October to March), although most severe events are generally concentrated between December and February. During the 
remaining months wave conditions are moderate, even though energetic events occasionally occur, with $H_{s o}$ exceeding $3 \mathrm{~m}$ (e.g. April 2008 or September 2008). The seasonal character of the wave climate in southwestern Portugal is highlighted by the 3-month running average in Figure 2. Both $H_{s o}$ and $T_{p}$ display a similar seasonal variation, with average $H_{s o}$ around $2 \mathrm{~m}$ and $T_{p}$ above $12 \mathrm{~s}$ in the peak of the winter season. Summer values range between 1 and $1.5 \mathrm{~m}$ and 8 and $10 \mathrm{~s}$ for $H_{s o}$ and $T_{p}$, respectively. Average wave approach from WNW to NW shows little seasonal variation.
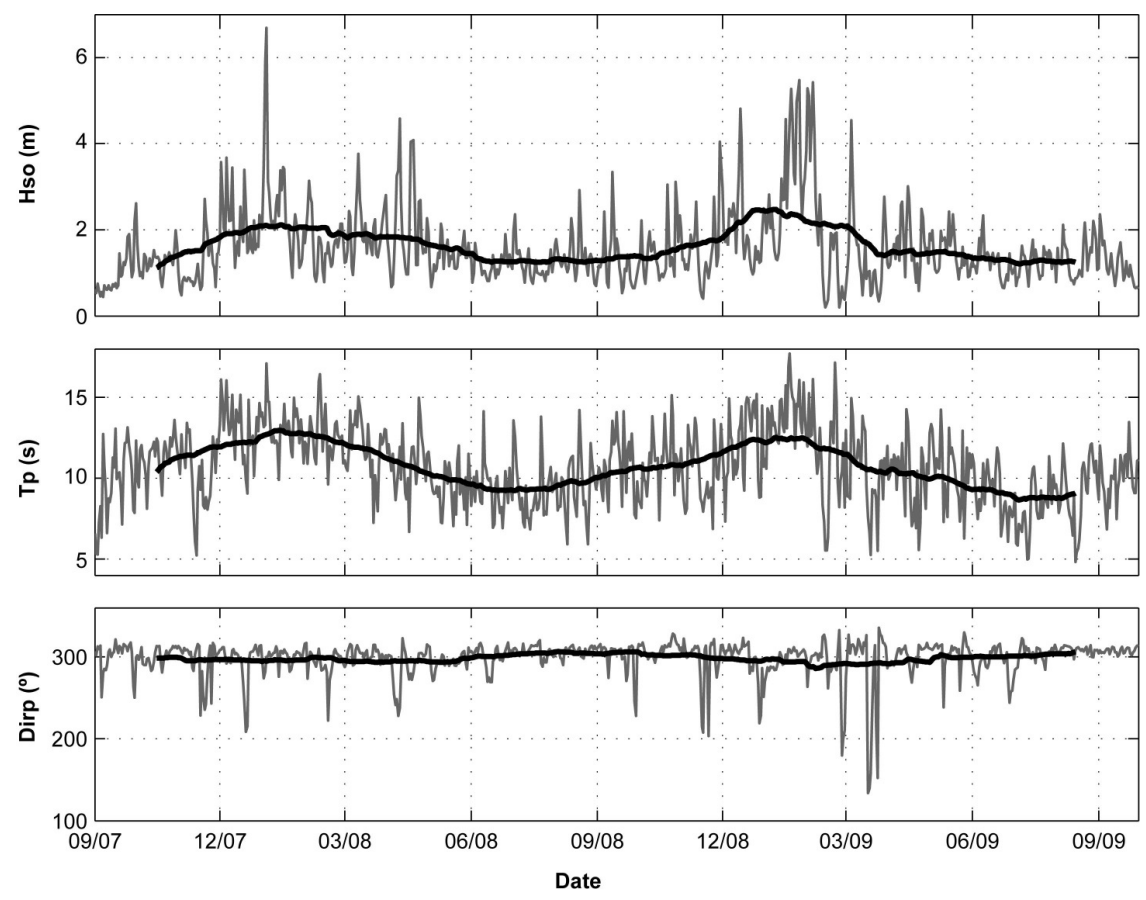

Fig. 2. Daily averages of offshore wave conditions for Sines buoy between September 2007 and September 2009. Thick black line depicts smoothed values using a 3-month running average

The most significant events during the monitoring period occurred in January 2008 and January-February 2009 (Figure 2). An extreme single storm, with daily $H_{s o}$ exceeding $6 \mathrm{~m}$ and maximum $H_{s o}$ up to $8 \mathrm{~m}$, reached the coast during neap tide in early January 2008, with waves in excess of $5 \mathrm{~m}$ for 36 hours. By mid-January 2009 a series of storms in rapid succession was initiated, lasting for 22 days with continuously high waves. Considering a storm independence criterion of 30 hours between wave extremes, following Morton et al. (1997) according to the time-scale of mid-latitude depressions, 5 individual storms 
compose this storm group (Figure 3). The storm group spanned through neap and spring tides, although no storm peak was coincident with the highest tides between the $27^{\text {th }}$ and $31^{\text {st }}$ of January. Surge levels were significant, especially during the $4^{\text {th }}$ and $5^{\text {th }}$ storms, but maximum surge of $0.32 \mathrm{~m}$ did not reach the threshold of $0.35 \mathrm{~m}$ defined by Gama et al. (1994) as the yearly very significant surge level (above the $99^{\text {th }}$ percentile) for the southwestern coast of Portugal.

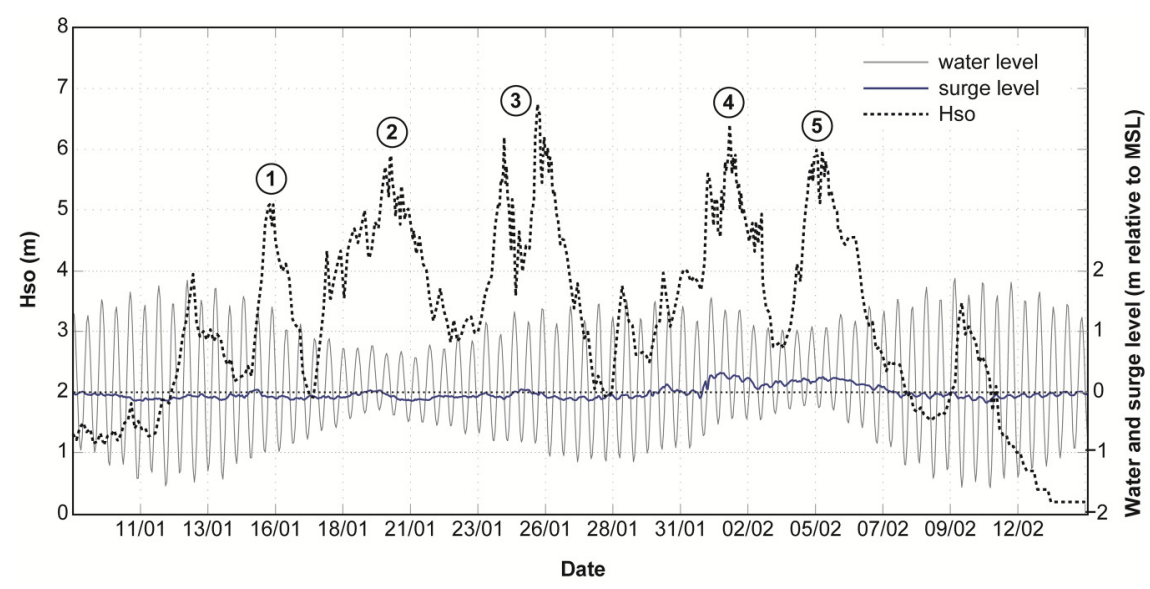

Fig. 3. Offshore significant wave height, water level and surge level during the January-February 2009 storm group

\section{Seasonal and storm induced beach change}

Morphological change was evaluated using the variation of beach profile volume above MLWS level and beach width up to MSL (Figure 4). Both proxies for beach change are significantly correlated at every profile $(R \geq 0.80, \rho \leq$ $0.001)$, except Amoreira south profile $(R=0.31, \rho>0.05)$. Peak profile volumes and widths are generally recorded in late October to early November, following a gradual accretion during the summer months. Abrupt changes took place during the winter, especially during the months of December to February, when high-energy events are more frequent. During the first year of monitoring the mean beach variation, in either volume or width, fluctuated between $\pm 100 \mathrm{~m}^{3} / \mathrm{m}$ for profile volume and $\pm 50 \mathrm{~m}$ for beach width. The variation in most individual profiles was also within these ranges, with exceptions of Amoreira north and south profiles and also Monte Clérigo south profile. By early November 2008 most profiles presented volumes or widths similar to the ones recorded in November 2007, before the winter storms, suggesting a yearly cycle characterized by winter erosion and summer accretion, without significant sediment loss. Within this general seasonal variation in mean beach volume or width, however, individual profiles exhibit shorter term cyclic changes related to 
storm - post-storm cycles. Profiles Amoreira south and north, Monte Clérigo north and Arrifana south reveal more clearly these cycles that, despite the shorttimescale, still involve sediment volumes and beach width changes similar to the values previously reported for the mean beach variation.
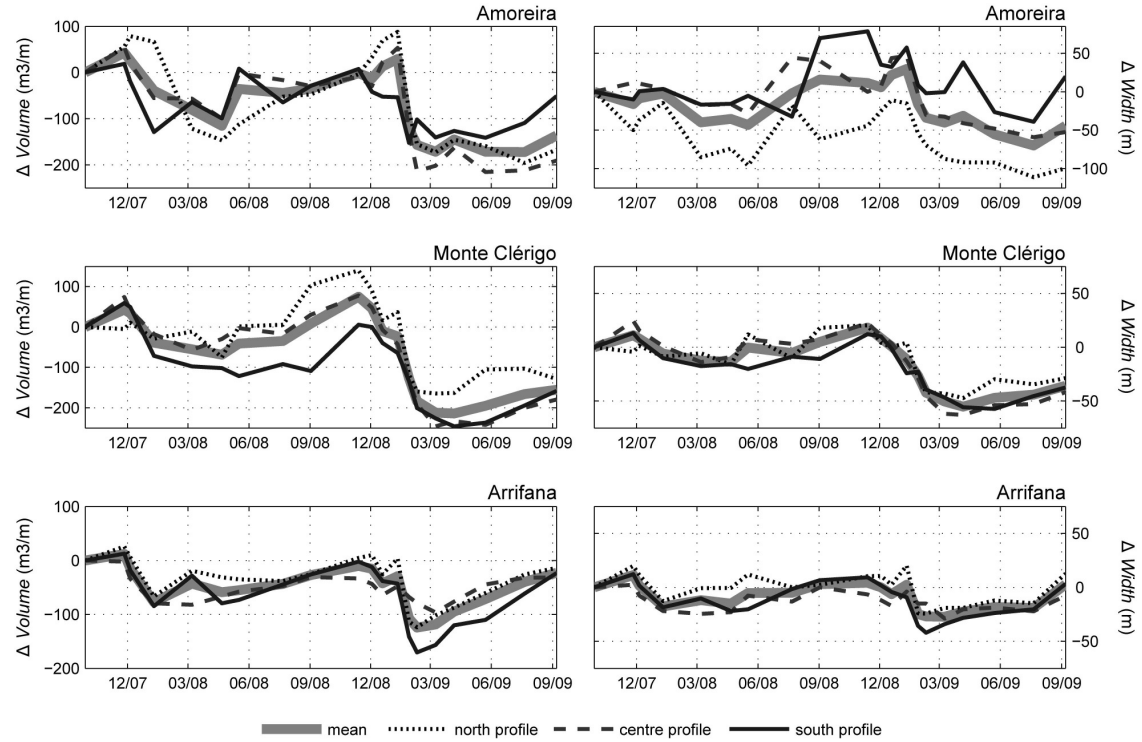

Fig. 4. Cumulative beach change for each profile and averaged per beach. Left panels represent the beach volume $\left(\mathrm{m}^{3} / \mathrm{m}\right)$ and beach width $(\mathrm{m})$ is shown in the right panels.

The January-February 2009 storm group promoted general erosion on all three beaches, being responsible for the most dramatic changes during the monitoring period. Erosion of 100 to $200 \mathrm{~m}^{3} / \mathrm{m}$ occurred on most profiles during this cluster of 5 storms, and average shoreline retreat was $40 \mathrm{~m}$. The response of the beaches to this storm group was not uniform, and there were variations especially in terms of magnitude of beach width change. These variations are evident in Amoreira beach, where changes are of higher magnitude (note the different y axis scale in Figure 4). Following the storm group, beach recovery initiated immediately in Arrifana beach, while Amoreira and Monte Clérigo beaches still experienced moderate erosion, reaching the lower sediment volumes by the beginning of the 2009 summer season, after which beach recovery was initiated.

By the end of the monitoring period net sediment loss was significant in Amoreira and Monte Clérigo beaches, amounting to approximately $150 \mathrm{~m}^{3} / \mathrm{m}$ with a corresponding net shoreline retreat of roughly $50 \mathrm{~m}$. Sediment losses were, however, restricted to the foreshore, resulting in significant berm retreat 
and intertidal beach lowering. Despite the significant erosion observed, mostly under the action of the January-February 2009 storm group, there was no dune scarping or retreat on the profiles backed by dunes in Amoreira and Monte Clérigo beaches.

\section{Alongshore non-uniform beach change}

Regardless of the reduced dimensions of the three beaches, with lengths of less than $1 \mathrm{~km}$, differences in beach profile response within each beach were observed. Alongshore variations in profile response are generally in terms of magnitude of change, since erosion and deposition were mostly synchronous in all profiles. Differences in profile variation within the same beach reached maximum values of $200 \mathrm{~m} / \mathrm{m}$ in volume (Monte Clérigo beach in September 2008; Figure 4), or $100 \mathrm{~m}$ in width (Amoreira beach in September 2008; Figure 4). The non-uniform beach response is evident in the mobility and envelopes of change for each profile (Figure 5). Alongshore ranges for both envelope and mobility in Amoreira beach are similar for profiles north and centre, while for profile south both indexes are approximately $50 \mathrm{~m}^{3} / \mathrm{m}$ smaller in both positive (accretion) or negative variation (erosion), indicating lower range of variation. Monte Clérigo beach evidences also alongshore variations in profile variability, with the centre profile presenting a wider mobility. Considering absolute ranges of profile envelope at Monte Clérigo, all profiles present envelopes around 300 $\mathrm{m}^{3} / \mathrm{m}$, but the envelope of profile centre presents lower values, indicating higher erosion. Profile mobility and envelopes at Arrifana beach also show distinct alongshore variations. Profiles south and north present approximately twice the profile centre mobility, and change envelopes are significantly wider, implying that profile centre is less variable than the profiles at both ends of the beach. It is important to note that the magnitude of change in terms of average mobility and envelope is similar between Amoreira and Monte Clérigo, and both are approximately twice the average values for Arrifana.

Profile behaviour was also marked by diverse association between profiles at each embayment, as confirmed by correlation of temporal changes of volume and width for individual profiles within each beach (Table 1). Significant correlation was found between Amoreira north and centre profiles, for both volume $(R=0.86, \rho<0.01)$ and width $(R=0.82, \rho \leq 0.01)$, while profile south was uncorrelated to any other profile in terms of beach width. For Monte Clérigo there is a slightly higher agreement between profiles south and centre, despite all profiles being well correlated in both volume and width $(R \geq 0.76, \rho<$ 0.05). At Arrifana higher correlation is found between profiles at each end of the beach, where profiles north and south present the highest correlation for beach volume $(R=0.96, \rho<0.01)$, despite being $400 \mathrm{~m}$ apart. 


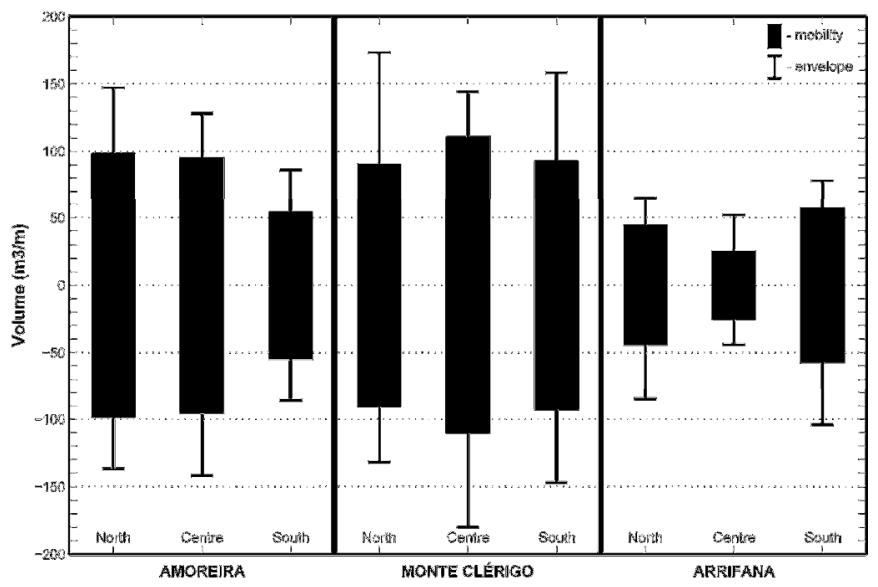

Fig. 5. Profile volumetric mobility and envelope

Table 1. Correlation coefficients for beach profile volume and width variation

\begin{tabular}{llll}
\hline Profile Name & AMN & AMC & AMS \\
\hline AMN & & $0.82 *$ & $0.29 * * *$ \\
AMC & $0.86 *$ & & $0.41 * * *$ \\
AMS & $0.51 * *$ & $0.75 *$ & \\
\hline Profile Name & MCN & MCC & MCS \\
\hline MCN & & $0.91 *$ & $0.81 *$ \\
MCC & $0.89 * *$ & & $0.95 *$ \\
MCS & $0.76 * *$ & $0.92 * *$ & \\
\hline Profile Name & ARN & ARC & ARS \\
\hline ARN & $0.73 *$ & $0.67 *$ & $0.82 *$ \\
ARC & $0.96 *$ & $0.75 *$ & $0.68 *$ \\
ARS & & & \\
\hline
\end{tabular}

* statistically significant for $\rho<0.01$

** statistically significant for $\rho<0.05$

*** statistically not significant

Note: Correlation for profile volume at the left side (no shading) and correlation for profile width at the right side (in light gray shading)

\section{Discussion and conclusion}

Seasonality in the wave forcing drives a seasonal cycle in beach change, particularly in swell-dominated beaches (Quartel et al., 2008), and was notable in the three beaches during the first year of monitoring, despite the occurrence of an extreme single storm in January 2008. Nevertheless, over the two-year period 
of monitoring, the temporal variation at the three embayed beaches suggests that the seasonal winter erosion/summer accretion pattern of morphological change is not the dominant signal in the data. The occurrence of a storm group in January-February 2009 created the most conspicuous change, highlighting the importance of storm groups as drivers of morphological change. Storm clustering over weekly to monthly timeframes has been shown to produce highly significant erosion on exposed sandy beaches of western Portugal (Ferreira, 2005), eastern Australia (Thom, 1974) and the US Pacific northwest coast (Ruggiero et al., 2005). Such extreme event grouping, by inducing severe erosion may require recovery periods of several years, promoting interannual variability that is noticeable in the beach and volume time series for Amoreira and Monte Clérigo beaches.

Despite a similar general evolution pattern, differences between beaches have also been observed, and these are mostly the result of geomorphologic constrains specific to individual beaches, as embayed coastlines are prone to site-specific storm responses (Cooper et al., 2004). Higher envelopes of shoreline change are expected for inlet-associated embayed beaches in comparison to headland-embayment systems in high-energy dissipative environments (Cooper et al., 2007; O'Connor et al., 2007). At Amoreira, the existence of a tidal stream that migrates and meanders across the intertidal beach influences shoreline variation, resulting in a more varied behaviour of beach width compared to the other two beaches. This higher shoreline variability within the embayment, however, is not matched by high volumetric variability. This suggests that sediment exchanges between the intertidal and subaerial beach affect the shoreline position but not the overall sediment volume. Local geomorphologic constraints are also responsible for lower magnitude volume and width changes at Arrifana beach. Diffraction around the prominent northern headland and refraction on the gentle shoreface significantly reduce breaking wave heights from the dominant north-westerly waves, leading to lower energy wave conditions compared to Amoreira and Monte Clérigo. Because of lower waves and higher confinement of Arrifana embayment, storm impacts are likely to be less severe. This is confirmed by the lower mobility and envelopes of change, as well as by the ability of the beach to regain its sediment volume and width by the end of 2009 summer, in contrast to Amoreira and Monte Clérigo, which experienced net erosion of $>100 \mathrm{~m}^{3} / \mathrm{m}$ and shoreline retreat of $\sim 50 \mathrm{~m}$.

Embayed high-energy dissipative beaches exposed to modally energetic swell are considered to be attuned to high-energy conditions and, therefore, require extreme events to cause significant morphological change (Cooper et al., 2004). Despite $H_{s o}$ reached a maximum of $8 \mathrm{~m}$ during the January 2008 storm, the short duration of the event and its occurrence during neap tides, led to only moderate erosion (within what is assumed to be the seasonal variation). The response to 
the January-February 2009 storm group was, however, much more significant even though maximum $H_{s o}$ was significantly lower, not even reaching $7 \mathrm{~m}$. As erosion on high-energy dissipative beaches is not directly related to the incident storm waves, but with the lower frequency motions generated in the inner surf zone (Russell, 1993), the duration of the storm events and their occurrence during periods of elevated water levels during spring high tide or significant surges, seem to be more important in determining beach response. When storm waves persist for long periods of time, as in the January-February 2009 storm group, infragravity motions, with their dominant offshore directed sediment transport (Russell, 1993), provide conditions for continued sediment erosion, leading to the extreme erosion observed in all beaches. Such extreme erosion on Amoreira and Monte Clérigo beaches had, however, no effect in the dunes and was restricted to the beach and nearshore. The ability of dissipative embayed coastlines to accommodate increasingly high waves, due to energy dissipation on progressively wider surf zones (Cooper et al., 2004), implies that most of the waves that reach the backshore are already not competent for inducing significant morphological change, as observed in Monte Clérigo and Amoreira. At the same level, the infragravity motions that convey the energy of the storm waves to the inner surf zone and beach, creating pulses of offshore sediment transport (Russell, 1993), are not active beyond the foreshore and therefore are unable to impact the backshore and dune. This has implications for the longterm behaviour of dissipative embayed coastlines, as even extreme events, if followed by moderate conditions that enable beach recovery, may not have long lasting effects on the coastline behaviour.

Variations in magnitude (but not overall pattern) of change were observed in each embayment. Embayment topography, particularly the presence of rocky headlands, significantly impacts morphodynamics of embayed beaches (Short, 1999). During high wave conditions the topographical influence of headlands on the surf zone dynamics is increased, inducing longshore gradients and forcing the development of cellular circulation (Short, 1985). Under these conditions, megarips develop and become the major mechanism of surf-zone circulation (Short, 1985; 1999), creating conditions for alongshore variation in beach response (Eliot and Clarke, 1982). Observations of surf-zone conditions during high waves on the three beaches, along with the measurement of profile change immediately after storms, confirmed the presence of megarips and quantified their impact on beach morphological change. Large rip channels connected to deep feeder channels along the intertidal beach were observed on the centre of Amoreira and Monte Clérigo embayments, while at Arrifana two megarips developed at both extremities of the beach. Profile erosion was always higher in the profiles fronting megarips or intersected by feeder channels, as evidenced in Arrifana. Similarity in behaviour of profiles north and south for Arrifana beach, for both volume and width (Table 1), supports the hypothesis that megarips are 
responsible for alongshore variability in profile and shoreline change in embayed beaches (Eliot and Clarke, 1982). The development of a megarip in the centre of Monte Clérigo embayment is also associated with higher profile mobility (Figure 5). Similarly, increased variability was observed in profiles centre and north in Amoreira beach, as the wide megarip developed in the centre of the beach migrated towards the northern section.

Extreme erosion on high-energy dissipative embayed beaches (as experienced during storm groups) appears to be associated with the development of cellular circulation with megarips persisting for extended periods of time. Because megarips tend to occupy topographically fixed positions on the beach, they induce variations in morphological change even along small beaches. High temporal and spatial variability in high-energy embayed beaches can, therefore, be expected, with significant deviations from the seasonal signal and alongshore non-uniform responses.

\section{Acknowledgements}

This work is a contribution to BAYBEACH project, funded by FCT under contract PTDC/CTE-GEX/66893/2006. CL was also supported by FCT, grant SFRH/BD/27878/2006. We gratefully acknowledge the help of everyone involved in the fieldwork. Hydrodynamic data from Sines was provided by Instituto Hidrográfico. WANA wave data was kindly supplied by Puertos del Estado.

\section{References}

Almeida, L.P., Ferreira, Ó. and Pacheco, A. (in press). "Thresholds for morphological changes on an exposed sandy beach as a function of wave height", Earth Surface Processes and Landforms.

Cooper, J.A.G, Jackson, D.W.T., Navas, F., McKenna, J. and Malvarez, G. (2004). "Identifying storm impacts on and embayed, high-energy coastline: examples from western Ireland”, Marine Geology, 210 (1-4), 261-280.

Cooper, J.A.G., McKenna, J., Jackson, D.W.T., O’Connor, M. (2007). "Mesoscale coastal behaviour related to morphological self-adjustment", Geology, 35 (1), 187-190.

Costa, M. and Esteves, R. (in press). "Clima de agitação marítima na costa oeste de Portugal Continental”, In Comunicações das XI Jornadas Técnicas de Engenharia Naval, Instituto Superior Técnico, Lisboa, 15 p. 
Costa, M., Silva, R. and Vitorino, J. (2001). "Contribuição para o estudo do clima de agitação marítima na costa Portuguesa”, In 2as Jornadas de Engenharia Costeira e Portuária. CD-ROM Published by AIPCN, Aveiro, 20 p.

Dolan, R., Hayden, B. and Heywood, J. (1978). "A new photogrammetric method for determining shoreline erosion", Coastal Engineering, 2, 21-39.

Eliot, I.G. and Clarke, D.J. (1982). "Seasonal and biennial fluctuation in subaerial beach sediment volume on Warilla beach, New South Wales", Marine Geology, 48 (1-2), 89-103.

Farris, A.S. and List, J.H. (2007). Shoreline change as a proxy for subaerial beach volume change", Journal of Coastal Research, 23 (3), 740-748.

Fox, W.T. and Davis, R.A. (1978). "Seasonal variation in beach erosion and sedimentation on the Oregon coast", Geological Society of America Bulletin, 89 (10), 1541-1549.

Ferreira, Ó. (2005). "Storm groups versus extreme single storms: Predicted erosion and management consequences", Journal of Coastal Research, SI $42,221-227$.

Gama, C., Dias, J.M.A., Ferreira, Ó. and Taborda, R. (1994). "Analysis of storm surge in Portugal, between June 1986 and May 1988”, In Proceedings of Littoral'94. EUROCOAST, Lisbon, 381-387.

Hansen, J.E. and Barnard, P.L. (2010). "Sub-weekly to interannual variability of a high-energy shoreline", Coastal Engineering, 57 (11-12), 959-972.

Hayes, M.O. and Boothroyd, J.C. (1969). "Storms as modifying agents in the coastal environment", In Beach and Nearshore Sediments and Processes, SEPM Reprint Series Number 12, 25-39.

Jackson, D.W.T, Cooper, J.A.G and del Rio, L. (2005). "Geological control of beach morphodynamic state", Marine Geology, 216 (4), 297-314.

Lahoz, M.G. and Albiach, J.C.C. (2005). "Wave forecasting at the Spanish coasts", Journal of Atmospheric \& Ocean Science, 10 (4), 389-405.

MacMahan, J.H., Thornton, E.B. and Reniers, A.J.H.M. (2006). "Rip current review", Coastal Engineering, 53 (2-3), 191-208 
Morton, I.D., Bowers, J. and Mould, G. (1997). "Estimating return period wave heights and wind speeds using a seasonal point process model", Coastal Engineering, 31 (1-4), 305-326.

Nordstrom, K.F. (1980). "Cyclic and seasonal beach response: a comparison of Oceanside and bayside beaches", Physical Geography, 1 (2), 177-196.

O'Connor, M., Cooper, J.A.G, Jackson, D.W.T. (2007). "Morphological behaviour of headland-embayment and inlet-associated beaches, Northwest Ireland", Journal of Coastal Research, SI 50, 626-630.

Pita, C. and Santos, J.A. (1989). "Análise dos temporais da costa oeste de Portugal Continental”. Technical Report NATO PO-WAVES 1/89-A, IH/LNEC, Lisboa.

Quartel, S., Kroon, A. and Ruessink, B.G. (2008). "Seasonal accretion and erosion patterns of a microtidal sandy beach", Marine Geology, 250 (1-2), 19-33.

Ruggiero, P., Kaminsky, G.M., Gelfenbaum, G. and Voigt, B. (2005). "Seasonal to interannual morphodynamics along a high-energy dissipative littoral cell”, Journal of Coastal Research, 21 (3), 553-578.

Russell, P.E. (1993). "Mechanisms for beach erosion during storms", Continental Shelf Research, 13 (11), 1243-1265.

Short, A.D. (1985). "Rip-Current Type, Spacing and Persistence, Narrabeen Beach, Australia”, Marine Geology, 65 (1-2), 47-71.

Short, A.D. (1999). "Handbook of Beach and Shoreface Morphodynamics", John Wiley \& Sons, 379 p.

Thom, B.G. (1974). "Coastal erosion in Eastern Australia", Search, 5 (5), 198209.

Wright, L.D., Guza, R.T. and Short, A.D. (1982). "Dynamics of a high-energy dissipative surf zone", Marine Geology, 45 (1-2), 41-62.

Wright, L.D. and Short, A.D. (1984). "Morphodynamic variability of surf zones and beaches - a synthesis", Marine Geology, 56 (1-4), 93-118. 